\title{
The Estimation of a Carbon Footprint for a Debris Flow Disaster - A Case Study in Daniau Community in Taitung, Taiwan
}

\author{
Peng Szu-Hsien
}

\begin{abstract}
In recent years, global warming and the greenhouse effect have created environmental issues around the world. Carbon footprint refers to the product, service or an event in a life cycle that is a result of human activity or which increases the global release of all greenhouse gases. Carbon footprint calculations allow enterprises to reduce carbon emissions and to improve product manufacturing processes. Many countries are actively expanding carbon footprint-related policies and studies. This study calculates the carbon footprint for a debris flow disaster. A FLO-2D is used to simulate a scenario and the resulting deposition depth, flow velocity and the affected area are determined. A life-cycle assessment method is then used to estimate the carbon footprint of reconstruction projects in Daniau Community in Taitung, Taiwan due to the debris flow that was induced by Typhoon Morakot. This study establishes an assessment model for the carbon footprint that can be used to assist future disaster reconstruction works.
\end{abstract}

Index Terms-Carbon footprint, debris flow disaster, FLO-2D model, scenario simulation.

\section{INTRODUCTION}

After the Industrial Revolution, rapid development and economic growth in many countries became a major source of greenhouse gas emissions and pollution problems. In 2007, the IPCC (Intergovernmental Panel on Climate Change) [1] reported a great increase in greenhouse gas (GHG) emissions due to activities in the past decades. Carbon dioxide $\left(\mathrm{CO}_{2}\right)$ was identified as the major cause of the greenhouse effect. To estimate Hurricane Katrina's carbon footprint for the forests along the Gulf of Mexico in 2005, the previous study [2] developed a Monte Carlo Method-discriminated estimation for tree damage and mortality rate that used satellite images to estimate or predict future carbon dioxide emissions.

Located in geologically unstable southeastern Taiwan in an area where there are frequent earthquakes, typhoons and heavy rainfall often result in serious debris flow disasters in Taitung, Taiwan. In 2009 Typhoon Morakot became a moderate typhoon and moved westwards at 20:00 on August 5. When the typhoon hit eastern Taiwan offshore, the topography of the land slowed the typhoon and it turned to the northwest. The Central Weather Bureau of Taiwan gave a land alarm at 8:30 on August 6. Around at 23:50 on August 7,

Manuscript received September 26, 2017; revised January 23, 2018. This work was supported in part by the grants from Chienkuo Technology University (CTU-103-RP-SD- 001-015-A).

S. H. Peng is with the Spatial Design Department, Chienkuo Technology University, Changhua City 500, Taiwan (e-mail: shpeng@ctu.edu.tw).
Typhoon Morakot landed in eastern Taiwan near Hualien City. It set a new record for rainfall in many regions in central, southern and eastern Taiwan, and caused severe flooding and major disasters in Tainan, Kaohsiung, Pingtung and Taitung counties. Many serious landslides and debris flows resulted in traffic disruption on railways or highways due to the loss of subgrade. A typhoon alert was released at 5:30 on August $10[3]$.

Most previous studies contain case studies of flood and debris flow disasters and carbon, water or ecological footprint [4]-[9]. Using flood or debris disasters and the carbon footprint limits studies. This study determines the carbon footprint for a debris flow disaster in Daniau Community of Taitung, Taiwan which suffered from Typhoon Morakot. A case study is undertaken to demonstrate the practicability of the evaluation method that is proposed in this paper. This produces a simple method to assess the carbon footprint for a debris flow disaster.

\section{MATERIALS AND METHODS}

\section{A. Study Area}

The study area, Daniau Creek Watershed, is located in southeast Taiwan and has an unstable geology due to frequent earthquakes. Taitung County has been affected by severe sediment disasters that were caused by typhoons and heavy rainfall for approximately the past 30 years. The total area of the watershed is $1,780.51$ ha and the elevation above sea level is $738 \mathrm{~m}$. The geology and soil conditions include the Miocene Lushan Formation, which is composed of argillite, slate and phyllite that is mixed with sandstone. The soil is primarily yellow soil and there is an area of 1,083.04 hectares, which comprises $60.83 \%$ of the total area. Colluvial soil accounts for 390.88 hectares. Daniau Creek is the main stream in this catchment and flows eastward. The length of the main stream is $7,150 \mathrm{~m} \mathrm{[3].}$

Typhoon Morakot landed in Taiwan on August 9 in 2009 and caused landslides upstream of the potential debris flow torrent (No. DF097). Much sediment moved down to the mid-stream exit of the river and buried and destroyed many residences in the downstream Daniau settlement. The movement of sediment down river caused a second overflow in the river behind a residence in Daniau Village, because a downstream bridge opening became blocked. The debris flow spread along the right bank of the river and resulted in several residences being undermined by sediment. A study [3] showed that the landslide area in Daniau Community was about 6.81 hectares and the amount of sediment was about 
0.32 million cubic meters. Not including the urgent dredging sediment of 0.26 million cubic meters and the loss of stream flow of 27,000 cubic meters, about 33,000 cubic meters of sediment remained in the upstream area. The landslide area in Daniau Community and the catchments, DF097 and DF098, are shown in Fig. 1.
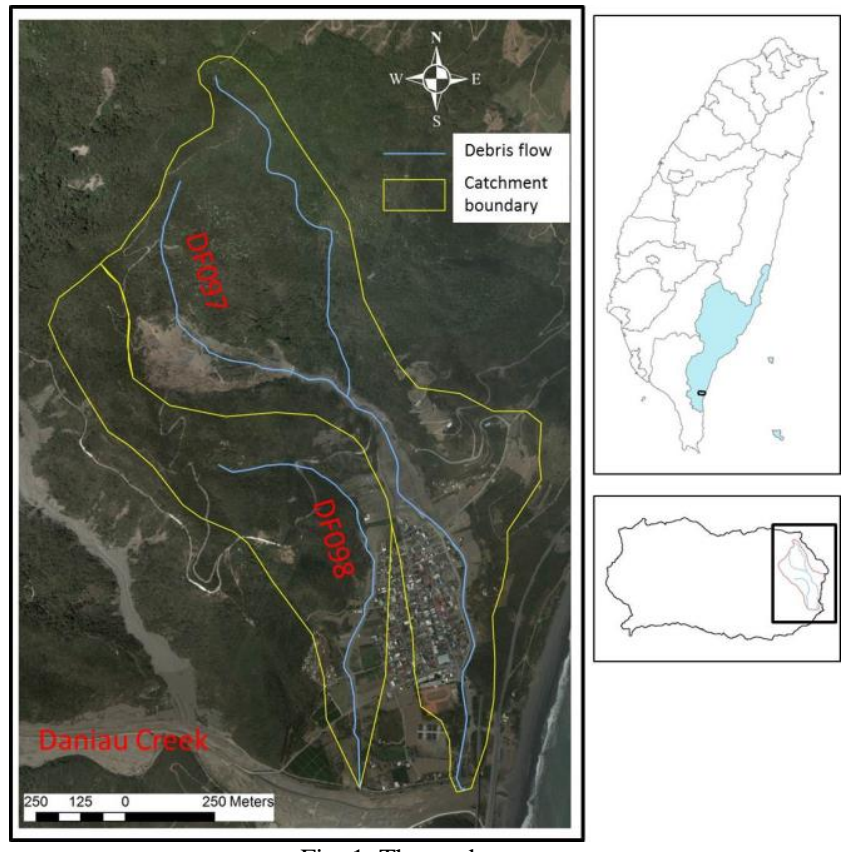

Fig. 1. The study area.

\section{B. Hydrological Analysis}

Usually, the catchment hydrological characteristics for the watershed and other relevant information are collected for hydrology analysis, to calculate the design peak flow for the watershed. According to Article 17 of the Soil and Water Conservation Technical Specification [10], the peak flow is estimated using unit hydrographs for previous discharge records for which there is measured data in the catchment. The peak flow is calculated using the unit hydrograph method, which uses rainfall records, if the catchment area is more than 1,000 hectares and there are no historical discharge records. Rational Formula can be used to estimate the peak flow if the catchment area is less than 1,000 hectares and there is no measured data.

The Horner formula is used to determine the rainfall pattern [11]. A series of more representative typhoons or torrential rainfall events during a continuous 24 hours can also be used to estimate the rainfall pattern. Deriving the percentage of each time period in terms of the total rainfall amount due to these events, as measured at rainfall stations, and then rearranging the rainfall for each time period using the average rainfall with the same rank gives the rainfall pattern for 24 hours. Another method uses the actual rainfall pattern for a specific single event. Using the Horner formula or the average method with the same rank, sign different rainfall patterns are determined using frequency analysis. The peak flow is estimated using the triangle unit hydrograph and the actual rainfall pattern.

A triangular unit hydrograph is used for the calculation in this study. The relationship between the triangular unit hydrograph base period $T_{b}$, the peak discharge $Q_{p}$, the peak arrival time $T_{p}$, and the watershed topographic factors is shown as follows [12]:

$$
\begin{gathered}
Q_{p}=\frac{0.208 A R_{e}}{T_{p}} \\
T_{p}=\frac{D}{2}+0.6 T_{c} \\
T_{c}=\frac{L}{W} \\
W=72\left(\frac{H}{L}\right)^{0.6} \\
T_{b}=T_{p}+T_{r}=2.67 T_{p}
\end{gathered}
$$

In the equations, $R_{e}=$ unit rainfall excess $(\mathrm{mm}), T_{p}=$ time for rise to peak flow (hr), $T_{r}=$ rainfall excess unit time (hr), $Q_{p}=$ peak discharge $\left(\mathrm{m}^{3} / \mathrm{s}\right), T_{c}=$ time of concentration $(\mathrm{hr})$, $T_{b}=$ discharge hydrograph base period (hr), $L=$ watershed mainstream length $(\mathrm{km}), H$ =watershed vertex-control point head $(\mathrm{km}), W=$ flood delivery velocity $(\mathrm{km} / \mathrm{hr}), A=$ watershed area $\left(\mathrm{km}^{2}\right)$, and $D=$ effective rainfall duration (hr). From these equations, $T_{r} 1 \mathrm{hr}$ and unit rainfall excess $R_{e} 10 \mathrm{~mm}$ are used to calculate the peak discharge.

\section{Scenario Simulation Using a Numerical Model}

A software package (FLO-2D) that was developed by FLO-2D Engrg., Inc. for floods and debris flows uses the non-Newton fluid model and the central finite difference scheme to solve motion-governing equations. This model can be used for flood disaster management, construction design, urban floods, mudflows and debris flows.

The FLO-2D software simulates a two-dimensional mudflow or debris flow to solve the average velocity, $u$, in the $x$-axis direction, the average velocity, $v$, in the $y$-axis direction and the flow depth, $h$. The governing equations are given as [13]:

Continuity equation:

$$
\frac{\partial h}{\partial t}+\frac{\partial(u h)}{\partial x}+\frac{\partial(v h)}{\partial y}=i
$$

Equation of motion:

$$
\begin{gathered}
S_{f x}=S_{b x}-\frac{\partial h}{\partial x}-\frac{\partial u}{g \partial t}-u \frac{\partial u}{g \partial x}-v \frac{\partial u}{g \partial y} \\
S_{f y}=S_{b y}-\frac{\partial h}{\partial y}-\frac{\partial v}{g \partial t}-u \frac{\partial v}{g \partial x}-v \frac{\partial v}{g \partial y}
\end{gathered}
$$

where $h$ is the flow depth (m), $u$ and $v$ are the respective depth-averaged velocities in the $x$ - and $y$-axis directions $(\mathrm{m} / \mathrm{s})$, $i$ is the excess rainfall intensity $(\mathrm{mm} / \mathrm{hr}), S_{f x}$ and $S_{f y}$ are the friction slope components, as given by Manning's equation or mudflow rheological model, for the $x$ - and $y$-axis 
directions, $S_{b x}$ and $S_{b y}$ are the respective bed slopes in the $x$ and $y$-axis directions and $g$ is acceleration of gravity $\left(\mathrm{m} / \mathrm{s}^{2}\right)$.

\section{Carbon Footprint Estimation}

Carbon footprint refers to all greenhouse gas emissions that are released globally or which are accumulated in the life cycle of products, services, or events because of human activities. The carbon footprint of products is calculated using a life cycle assessment for extraction, processing, and transportation at the front-end of the process and product use, regeneration, maintenance and recycling at the back-end, and the final discarding of the products. A life cycle assessment (LCA) "organizes and evaluates the input/output and potential environmental impact on the life cycle of a product system from the acquisition of raw materials to the final disposal" [14].

To simplify the calculation process, two major stages, urgent dredging and reconstruction of the Daniau Community [15] and the vegetation destroyed by the debris flow, are used to estimate the carbon footprint. In terms of reconstruction after a debris flow disaster, the carbon footprint uses the correlation between disasters and carbon emissions. The estimation of existing machines and tools, the number of times human resources are mobilized, the travelling distance, the life-support demands and the life cycle of space destruction could also be used to compare the difference between disaster mitigation and reconstruction [6], to prevent future disasters.

\section{RESUlTS AND DisCUSSION}

\section{A. The Inflow Hydrograph for Debris Flow}

Because there is no stage-discharge station in the study area, the data recorded by the Shao-Jia rainfall station for the Water Resources Agency in Taiwan is used. The Thiessen polygon method is used to determine the significance of rainfall gauges that are close to the research region. The results show that data from the nearest gauge, Shao-Jia Station, represents the entire watershed, so the rainfall histogram for the most important typhoon, Typhoon Morakot, is used as the actual rainfall pattern. The time of concentration is calculated using the catchment characteristics that are shown in Table I. Triangular unit hydrographs are also obtained using equations (1)-(5) and the inflow hydrographs for DF097 and DF098 are derived using these triangular unit hydrographs and the total rainfall $(1,412$ $\mathrm{mm}$ ) for Typhoon Morakot (see Fig. 2).

TABLE I: THE TIME OF CONCENTRATION AND CATCHMENT CHARACTERISTICS

\begin{tabular}{|c|c|c|c|c|}
\hline \multicolumn{5}{|c|}{ CHARACTERISTICS } \\
\hline $\begin{array}{l}\text { Catchment } \\
\text { No. }\end{array}$ & $\begin{array}{l}\text { Catchment } \\
\text { area (ha) }\end{array}$ & $\begin{array}{l}\text { Main } \\
\text { stream } \\
\text { length } \\
(\mathrm{km})\end{array}$ & $\begin{array}{l}\text { The } \\
\text { maximum } \\
\text { elevation } \\
\text { difference } \\
(\mathrm{m})\end{array}$ & $\begin{array}{l}\text { The time of } \\
\text { concentration } \\
(\mathrm{min})\end{array}$ \\
\hline DF097 & 83.89 & 3.383 & 520 & 25.51 \\
\hline DF098 & 42.27 & 1.276 & 407 & 13.57 \\
\hline
\end{tabular}

\section{B. Simulation of Debris Flow}

To simulate the terrain, a topographic map that is digitized using aerial photos from 2002 was transformed into a $10 \mathrm{~m} \times 10 \mathrm{~m}$ DEM. The debris flow parameters, including a volume concentration of $35 \%$, a yield stress of $204 \mathrm{~Pa}$, and a dynamic viscosity of $0.51 \mathrm{pa} \cdot \mathrm{s}$, from a previous study [16] were used to compute the simulation for the debris flow. The simulated results, including the maximum flow depths and the velocities of the computed domain during the simulated period, are shown in Fig. 3. The simulated results are in good agreement with the aerial photograph. The result for debris flow depth shows that the affected area is around 73,208 $\mathrm{m}^{2}$.

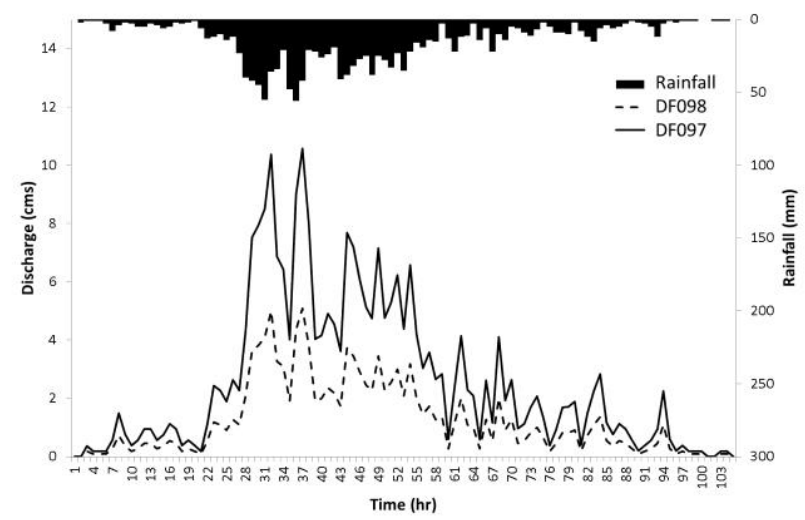

Fig. 2. The actual rainfall during Typhoon Morakot and the calculated inflow hydrographs for DF097 and DF098.

\section{Calculation of the Carbon Footprint}

The activity data and emission coefficients from previous studies [15], [17] are used for the calculation in this study. Urgent dredging and reconstruction engineering are the major considerations for the estimation of the carbon footprint and the detailed description was shown in the study [15]. A previous study [3] also showed that the amount of debris flow caused by Typhoon Morakot in Daniau Community that required urgent dredging was about 0.26 million $\mathrm{m}^{3}$. Although the dredging method was different at distinct stages, it is assumed that stream dredging was used, in order to simplify the calculation. The Cost Estimate Manual of Soil and Water Conservation Bureau in Taiwan [18] estimated the carbon footprint of urgent dredging, as shown in Table II.

To calculate the carbon emissions for reconstruction in Daniau Community, the major carbon emission items include concrete engineering and steel bar engineering, in addition to urgent dredging, and other items are temporarily ignored. The quantity of concrete and steel bar use the data from the relevant reconstruction design budget document, which is shown in Table III. For the example of Daniau Villiage in Taitung, the carbon emissions for concrete are about $65 \%$, followed by those for urgent dredging, at about $27 \%$, with those for steel bar the least, at $8 \%$. Concrete is the major carbon emission item for reconstruction using traditional engineering. In terms of the carbon reduction benefit, the use of concrete should be reduced or the regeneration materials should be increased in the future.

The additional carbon footprint of vegetation that was destroyed by the debris flow is also considered. The calculated area for the debris flow, using numerical simulation, is used to compute the carbon emissions if it is assumed that the carbon dioxide is not fixed by the destroyed 
vegetation (Table IV). The medium value of $600 \mathrm{~kg} / \mathrm{m}^{2}$ of $\mathrm{CO}_{2}$ as a fixed amount for trees is used and multiplied by the affected are of $73,208 \mathrm{~m}^{2}$, which is obtained using the FLO-2D figures in Fig. 3. The total amount of carbon footprint emissions, including those for affected vegetation, sediment dredging and reconstruction, is around 45,974,441 $\mathrm{kg}-\mathrm{eCO}_{2}$, and the amount of destroyed vegetation accounts for most $\left(43,924,800 \mathrm{~kg}-\mathrm{eCO}_{2}\right)$.

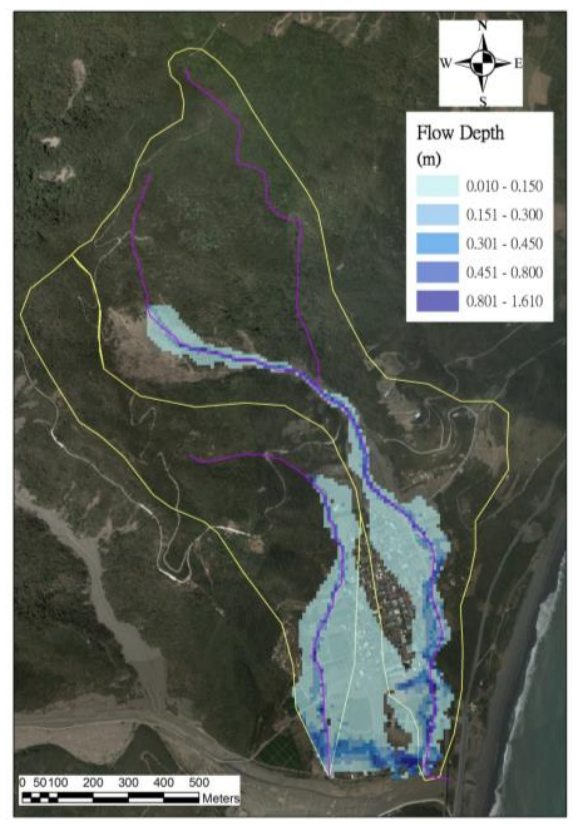

(a)

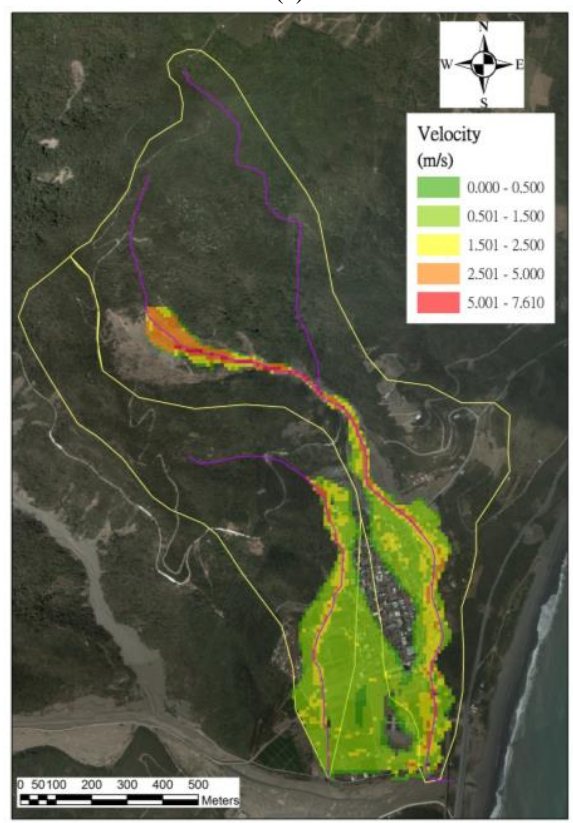

(b)

Fig. 3. Simulation results for the FLO-2D model: (a) the maximum flow depths; (b) the maximum velocities.

TABLE II: CARBON EMISSION CALCULATION FOR STREAM SEDIMENT DREDGING (SEE APPENDIX A)

\begin{tabular}{lcc}
\multicolumn{3}{c}{ DREDGING (SEE APPENDIX A) } \\
\hline \hline Inputs: & 260,000 & $\mathrm{~m}^{3}$ \\
\hline Dredging amount & 1.00 & $\mathrm{~km}$ \\
Haulage distance (to a convenient point in the & 2.12 & $\mathrm{~km}$ \\
stream) & & \\
Haulage distance (general highway) & 25 & $\mathrm{~km} / \mathrm{hr}$ \\
\hline Assumptions: & &
\end{tabular}

Average speed on the highway 40

Coefficient of loose conversion

$\mathrm{km} / \mathrm{hr}$

Coefficient of earth and stone volume

Coefficient of during bulldozing and

scraping, $K$

0.85

Work efficiency and site situation, $E$

Excavator type

Excavator quantity

Energy consumption for the excavator

Load carrying capacity of the haulage truck

0.75

0.7

10

10

8

11

Number of haulage trucks

Fuel consumption of a haulage truck

$\mathrm{CO}_{2}$ emissions for diesel fuel

$\mathrm{CO}_{2}$ emissions for operators

2.8

2.78

g- $\mathrm{CO}_{2} / \mathrm{L}$

Outputs:

\begin{tabular}{lrr}
\hline Total carbon emissions & 437,827 & $\mathrm{eKg}-\mathrm{CO}_{2}$ \\
\hline Average unit carbon emission & 1.68 & $\mathrm{eKg}-\mathrm{CO}_{2} / \mathrm{m}^{3}$ \\
Assumed working period & 85 & day \\
\hline \hline
\end{tabular}

TABLE III: ESTIMATION OF CARBON EMISSIONS FOR RECONSTRUCTION IN DANIAU

\begin{tabular}{lcrrr}
\hline \hline Construction & Unit & Quantity & $\begin{array}{l}\text { Unit carbon } \\
\text { emissions } \\
\left(\mathrm{kg}-\mathrm{eCO}_{2}\right)\end{array}$ & \multicolumn{2}{l}{$\begin{array}{l}\text { Total carbon } \\
\text { emissions } \\
\left(\mathrm{kg}-\mathrm{eCO}_{2}\right)\end{array}$} \\
\hline $\begin{array}{l}\text { Urgent } \\
\text { dredging }\end{array}$ & $\mathrm{m}^{3}$ & $260,000.000$ & 1.68 & $437,827.00$ \\
$\begin{array}{l}\text { Concrete } \\
\text { Steel bar }\end{array}$ & $\mathrm{m}^{3}$ & $13,493.000$ & 78.19 & $1,055,017.77$ \\
& ton & 132.369 & 898.77 & $118,969.29$ \\
\hline \hline
\end{tabular}

TABLE IV: CARBON DIOXIDE FIXED AMOUNT FOR DIFFERENT PLANTING TYPES [19]

\begin{tabular}{|c|c|c|c|}
\hline & Planting type & $\begin{array}{l}\mathrm{CO}_{2} \text { fixed } \\
\text { amount } \\
\left(\mathrm{kg} / \mathrm{m}^{2}\right)\end{array}$ & $\begin{array}{l}\text { Covering } \\
\text { soil depth }\end{array}$ \\
\hline $\begin{array}{l}\text { Ecological } \\
\text { multilayered }\end{array}$ & $\begin{array}{l}\text { Trees, shrubs, flowers and } \\
\text { high density hybrid zone } \\
\text { (3.0m tree spacing or less) }\end{array}$ & 1,200 & \multirow{4}{*}{$>1 \mathrm{~m}$} \\
\hline \multirow{3}{*}{ Trees } & Large-leaved trees & 900 & \\
\hline & $\begin{array}{l}\text { Small-leaved trees, } \\
\text { coniferous trees and sparsely } \\
\text { leaved trees }\end{array}$ & 600 & \\
\hline & Palm & 400 & \\
\hline \multicolumn{2}{|c|}{ Shrubs (planting at least 4 plants each $\mathrm{m}^{2}$ ) } & 300 & \multirow{2}{*}{$>0.5 \mathrm{~m}$} \\
\hline \multicolumn{2}{|c|}{ Perennial vines } & 100 & \\
\hline \multicolumn{2}{|c|}{$\begin{array}{l}\text { Flower gardens, natural grass land, aquatic } \\
\text { plants and lawns }\end{array}$} & 20 & $>0.3 \mathrm{~m}$ \\
\hline
\end{tabular}

\section{CONCLUSIONS}

A carbon footprint is defined as the carbon dioxide emissions that are directly and indirectly generated from an activity or a product over the entire life cycle. Natural disasters, such as floods and debris flows, cannot use the life cycle to estimate the carbon footprint. The carbon footprint is estimated indirectly by calculating the carbon dioxide emissions for reconstruction and destroyed vegetation. A construction engineering cost and material analysis is used to estimate the carbon footprint for reconstruction due to debris flow in Daniau Community in Taitung, Taiwan where the urgent dredging generates approximately estimated at about $437,827 \mathrm{~kg}-\mathrm{eCO}_{2}$ and other reconstruction generates $1,173,986.96 \mathrm{~kg}-\mathrm{eCO}_{2}$, when only concrete and steel bar are considered. Using FLO-2D to simulate the affected area for the debris flow and to compute the carbon footprint gives a 
value of around $43,924,800 \mathrm{~kg}-\mathrm{eCO}$. It is postulated that relevant disaster prevention programs that reduce the coverage and quantity of sediment disasters or reconstruction engineering that uses less concrete could reduce carbon emissions in the future. The numerical simulation could also be used to estimate effects more accurately.

\section{APPENDIX}

According to the survey conducted by the Taitung Branch of the Soil and Water Conservation Bureau [3], the urgent clearing of sediments due to Typhoon Morakot in Daniau Community was about $260,000 \mathrm{~m}^{3}$. Although different ways of clearing were used for different periods and areas, it is assumed that stream dredging was used to simplify the estimation [18], [20]. The carbon footprint was calculated as follows:

A.1 Assumptions: The distance between the dredging site and the fill area is $3.12 \mathrm{~km}$, including $1 \mathrm{~km}$ of the sidewalk (average speed of $25 \mathrm{~km} / \mathrm{hr}$ ) and $2.12 \mathrm{~km}$ of general road (average speed of $40 \mathrm{~km} / \mathrm{hr}$ ). Loose sediments $=260,000 \mathrm{~m}^{3}$ $\times 1.11=288,600 \mathrm{~m}^{3}$. Use a $0.7 \mathrm{~m}^{3}$ excavator with a 20 -ton dump truck for dredging.

A. 2 Workload calculation:

Time required for a truck:

$$
\begin{aligned}
t & =\left(90 \mathrm{sec}+8 \mathrm{~m}^{3} / 0.7 \mathrm{~m}^{3} / 10 \text { liters } \times 20 \mathrm{sec} / 10 \text { liters }\right) \\
& =319 \mathrm{sec}=5.31 \mathrm{~min}
\end{aligned}
$$

Excavator workload (actual working hours are 50 minutes per hour):

$$
\begin{aligned}
& W_{1}=(50 \mathrm{~min} / 5.31 \mathrm{~min}) \\
& \mathrm{m}^{3} / \mathrm{hr}
\end{aligned}
$$

Where: $f=$ the expansion coefficient of natural sediment volume converted by loose sediment; $K=$ the value for the bulldozing and scratching operation; $E=$ working efficiency and site factors. For this report, $f$ $=0.8, K=0.85$ and $E=0.75$ [20].

Workload of 20T truck $\left(8 \mathrm{~m}^{3}\right.$, net load $\left.=12.8 \mathrm{~T}\right)$ :

$C_{M}=t_{1}+t_{2}+t_{3}=5.31 \mathrm{~min}+1.5 \mathrm{~min}+(1 \mathrm{~km} / 25 \mathrm{~km} / \mathrm{hr}$

$+2.12 \mathrm{~km} / 40 \mathrm{~km} / \mathrm{hr}) \times 60 \mathrm{~min} / \mathrm{hr}=12.39 \mathrm{~min}$

Where: $C_{M}=$ cycle time, $t_{1}=$ loading and unloading time, $t_{2}=$ waiting time of 1.5 minutes and $t_{3}$ $=$ round trip time.

$W_{2}=60 \mathrm{~min} / 12.39 \mathrm{~min} /$ truck $\times 8 \mathrm{~m}^{3} /$ truck $=38.74$ $\mathrm{m}^{3} / \mathrm{hr}$

A3. Calculation of construction machinery working hours: Excavator $0.7 \mathrm{~m}^{3}:\left(260,000 \mathrm{~m}^{3}\right) /\left(38.42 \mathrm{~m}^{3} / \mathrm{hr}\right)=$ $6,767 \mathrm{hr}$

Workload for $20 \mathrm{~T}$ truck $\left(8 \mathrm{~m}^{3}\right.$, net load $\left.12.8 \mathrm{~T}\right)$ : $\left(288,600 \mathrm{~m}^{3}\right) /\left(38.74 \mathrm{~m}^{3} / \mathrm{hr}\right)=7,450 \mathrm{hr}$

A4. Working day calculations:

Excavator $0.7 \mathrm{~m}^{3}$ (10 units): $6,767 /(10 \times 8)=85$ days

$20 \mathrm{~T}$ truck $\left(8 \mathrm{~m}^{3}\right.$, net load $12.8 \mathrm{~T}, 11$ units): $7,450 /(11 \times 8)=85$ days

Working days are 85 days. Doubling the amount of construction machinery for the rush reduces the duration by half.

A5. Construction machinery carbon emissions:

For a $0.7 \mathrm{~m}^{3}$ excavator, assuming diesel fuel consumption is $10 \mathrm{~L} / \mathrm{hr}$, and $\mathrm{CO}_{2}$ emissions for diesel are $2.78 \mathrm{~kg}$ per liter.

$6,767 \mathrm{hr} \times 10 \mathrm{~L} / \mathrm{hr} \times 2.78 \mathrm{~kg}-\mathrm{eCO}_{2} / \mathrm{L}=188,122.60$ $\mathrm{kg}-\mathrm{eCO}_{2}$

For a 20T truck, assuming an average vehicle speed $=3.12 /(1 / 25+2.12 / 40)=33.55 \mathrm{~km} / \mathrm{hr}$ and fuel consumption $=2.8 \mathrm{~km} / \mathrm{L}$, then

$7,450 \mathrm{hr} \times 33.55 \mathrm{~km} / \mathrm{hr} / 2.8 \mathrm{~km} / \mathrm{L} \times 2.78$ $\mathrm{kg}-\mathrm{eCO}_{2} / \mathrm{L}=248,162.16 \mathrm{~kg}-\mathrm{eCO}_{2}$

The total is $436,284.76 \mathrm{~kg}-\mathrm{eCO}_{2}$

A6. Carbon emissions for operators:

The previous study [17] calculated the amount of carbon emissions for the site for concrete pouring personnel as 0.108 $\mathrm{kg}-\mathrm{eCO}_{2} / \mathrm{hr}$. Assuming that the figures for special craftsmen (excavator operators) and general technicians (truck drivers) are the same, then the carbon emissions for workers:

$(10+11) \times 85$ days $\times 0.864 \mathrm{~kg} /$ day $=1,542.24$ $\mathrm{kg}-\mathrm{eCO}_{2}$

A7. Total carbon emissions:

$(436,284.76+1,542.24)=437,827 \mathrm{~kg}-\mathrm{eCO}_{2}$

Average unit carbon emissions: 437,827 / 260,000 $=1.68 \mathrm{~kg}-\mathrm{eCO} \mathrm{CO}_{2}$

\section{REFERENCES}

[1] S. Susan, "Climate change 2007-the physical science basis: Working group I contribution to the fourth assessment report of the IPCC," London: Cambridge University Press, 2007.

[2] J. Q. Chambers, J. I. Fisher, H. Zeng, E. L. Chapman, D. B. Baker, and G. C. Hurtt, "Hurricane Katrina's carbon footprint on US Gulf Coast forests," Science, vol. 318, pp. 1107-1107, 2007.

[3] SWCB, Slopeland Conservation Investigation and Planning of Daniau Coastal Watershed, Nantou: Report of Soil and Water Conservation Bureau, Council of Agriculture, Taiwan, 2011.

[4] Y. Tie, R. Xu, and R. Ba, "The formation of runoff-generated debris flow in southwestern of China: take Gangou as an example," Environmental Earth Sciences, vol. 72, pp. 1479-1490, 2014.

[5] B. Yu, L. Li, Y. Wu, and S. Chu, "A formation model for debris flows in the Chenyulan River Watershed, Taiwan," Natural Hazards, vol. 68 pp. 745-762, 2013.

[6] J. J. Wang, "Large-scale debris flow disasters: hazard-riskvulnerability analysis approach in Taiwan," Conservation and Management of Archaeological Sites, vol. 18, pp. 449-463, 2016.

[7] H. Sharp, J. Grundius, and J. Heinonen, "Carbon footprint of inbound tourism to Iceland: a consumption-based life-cycle assessment including direct and indirect emissions," Sustainability, vol. 8, p. 1147, 2016.

[8] S. Rinaldi, E. Bonamente, F. Scrucca, M. Merico, F. Asdrubali, and F. Cotana, "Water and carbon footprint of wine: methodology review and application to a case study," Sustainability, vol. 8, p. 621, 2016.

[9] Á. de Miguel, M. Kallache, and E. García-Calvo, "The water footprint of agriculture in Duero River Basin," Sustainability, vol. 7, p. 6759, 2015 .

[10] SWCB, Technical Manual for Soil and Water Conservation, Nantou: Soil and Water Conservation Bureau, Council of Agriculture, Taiwan, 2005.

[11] WRPI, Reference Manual of River Management and Environmental Planning, Taichung: Water Resources Planning Institute, Water Resources Agency, Ministry of Economic Affairs, Taiwan, 2006.

[12] SWCB, Integrated Watershed Investigation and Planning Manual, Nantou: Report of Soil and Water Conservation Bureau, Council of Agriculture, Taiwan, 2008.

[13] J. S. O'Brien, P. Y. Julien, and W. T. Fullerton, "Two-dimensional water flood and mudflow simulation," Journal of Hydraulic Engineering, vol. 119, pp. 244-261, 1993.

[14] C. Trust, PAS 2050: 2011-Specification for the Assessment of the Life Cycle Greenhouse Gas Emissions of Goods and Services, London: Department for Environment, Food and Rural Affairs, \& British Standards Institution, 2011.

[15] S. H. Peng, C. Tang, C. C. Chen, M. J. Shieh, L. M. Huang, and W. E. Chen, "Carbon footprint estimation of reconstruction for a debris flow 
disaster in a hillside community," in Proc. 2014 International Conference on Civil, Urban and Environmental Engineering (CUEE 2014), pp. 269-276, 2014.

[16] S. H. Peng and S. C. Lu, "FLO-2D simulation of mudflow caused by large landslide due to extremely heavy rainfall in southeastern Taiwan during Typhoon Morakot," Journal of Mountain Science, vol. 10, pp. 207-218, 2013

[17] K. C. Wu, "Discussion on the public works to implement green connotation - in case of the Taoyuan Station Structural Engineering on Airport MRT," Master Thesis, Department of Civil Engineering, National Central University, 2011.

[18] H. L. Wu, Budget Principle for Soil and Water Conservation Construction and Cost Estimate Manual, Nantou: Soil and Water Conservation Bureau, Council of Agriculture, Taiwan, 2007.

[19] H. T. Lin, T. P. Lin, and Y. S. Tsai, Green Building Evaluation Manual-Basic Version, Taipei: Architecture and Building Research Institute, Ministry of the Interior, Taiwan, 2015.
[20] WRPI, Handbook of Hydraulics Engineering Wage Analysis, Taichung: Water Resources Planning Institute, Water Resources Agency, Ministry of Economic Affairs, Taiwan, 2011.

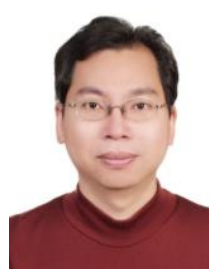

Szu-Hsien Peng is working as an associate professor a Chienkuo Technology University, Taiwan. He obtained his $\mathrm{PhD}$ from National Chung Hsing University. A numerical model for calculating 2D two-layers shallow water flows by using finite volume method was developed in his $\mathrm{PhD}$ research. Recently, his study interests most focus on computational hydraulics, debris flow disaster prevention, gis, risk management and landscape studies. 